\title{
Perjanjian Kerja Waktu Tertentu (PKWT) Dalam UU N0 13 Tahun 2003 Tentang Ketenagakerjaan Suatu Analis Maslahah Mursalah Dan Keadilan Pancasila
}

\author{
Aan Ahmad Sancoko \\ Magister Hukum Universitas Semarang
}

\begin{abstract}
ABSTRAK
Maksud dan tujuan penelitian ini adalah untuk menganalisa bagaimanakah pelaksanaan perjanjian kerja waktu tertentu (PKWT) oleh pengusaha terhadap karyawannya serta apa yang mendasari pengusaha mengikat karyawan dengan perjanjian kerja waktu tertentu (PKWT), bagaimana bentuk perlindungan hukum terhadap karyawan jika pengusaha telah melakukan wanprestasi dalam pelaksanaan perjanjian kerja waktu tertentu (PKWT). Metode yang digunakan dalam penelitian ini adalah dengan metode yuridis normative. Hasil penulisan ini pada akhirnya memberikan jawaban bahwa pelaksanaan PKWT oleh pengusaha terhadap karyawannya yaitu dengan penyusunan kontrak di kantor perusahaan yang dibuat menurut format yang dibuat oleh pengusaha dan tidak melalui penyusunan perjanjian secara bersama-sama. Mengenai bentuk perlindungan hukum terhadap karyawan jika pengusaha telah melakukan wanprestasi dalam pelaksanaan PKWT yaitu dibantu dengan pengawas dalam struktur Dinas Perindustrian dan Tenaga Kerja serta Lembaga Kerja Sama Tripartit (LKS Tripartit) yang merupakan forum komunikasi, konsultasi dan musyawarah tentang masalah ketenagakerjaan. Saran dari penelitian ini adalah kepada Dinas Perindustrian dan Tenaga Kerja diharapkan agar lebih memanfaatkan Sumber Daya Manusia (SDM) yang ada sehingga dapat terfokus pada suatu permsalahan yang ditanganinya menajalankan tugas dan perannya sesuai dengan ketentuan peraturan perundang-undangan yang berlaku agar lebih memperhatikan hak-hak dari Tenaga Kerja.
\end{abstract}

Kata kunci: Perjanjian Kerja Waktu Tertentu; pengusaha; karyawan 
$e-I S S N: 2621-4105$

\title{
Specific Time Work Agreement (PKWT) in Law NO 13 of 2003 concerning Employment of a Maslahah Mursalah Analyst and Pancasila Justice
}

\author{
Aan Ahmad Sancoko \\ Master of Law, University of Semarang
}

\begin{abstract}
The purpose and purpose of this study is to analyze the implementation of a specific time work agreement (PKWT) by employers against their employees and also what underlies employers bind employees with a certain time work agreement (PKWT), research on work relationships between companies and companies that help default in implementation A specific time employment agreement (PKWT). The method used in this study is the normative juridical method. The results of this agreement finally gave an answer to the implementation of PKWT by employers against their employees, namely by making agreements in the office of the company that were made according to a format made by employers and not through cooperation agreements with the same. Regarding the legal form of employees If the employer has defaulted on the implementation of PKWT, namely assisting with supervisors in the structure of the Department of Industry and Labor and Tripartite Cooperation Institution (LKS Tripartite) which is a communication, consultation and deliberation forum on labor issues. Suggestions from this research are for the Department of Industry and Labor which is expected to make better use of Human Resources (HR) which can be focused on a problem in which he handles his duties and roles in accordance with the provisions of the negotiation of Manpower.
\end{abstract}

Keywords: Work Agreement for a Specific Time; businessman; the employee 
e-ISSN : 2621-4105

\section{A. PENDAHULUAN}

Falsafah Pancasila menghendaki tercapainya keadilan sosial, yang lebih terperinci dinyatakan dalam Undang-Undang Dasar 1945 baik dalam Pembukaannya maupun dalam Pasal 27 ayat (2). Keadilan sosial baru akan tercapai apabila terdapat keseimbangan antara penyelenggaraan kebutuhan masyarakat sebagai satu keseluruhan dan kebutuhan perorangan sebagai bagian dari keseluruhan masyarakat ${ }^{1}$. Tujuan dan fungsi hukum Indonesia bukanlah sekedar memelihara ketertiban, keamanan, dan stabilitas masyarakat, akan tetapi lebih diarahkan pada cita-cita untuk mencapai kesejahteraan masyarakat Indonesia, baik dalam arti masyarakat sebagai satu kesatuan, maupun untuk mencapai kesejahteraan bagi setiap warga Indonesia.

Padahal sesuai dengan amanat Undang Undang dasar 1945 pada pasal 27 ayat (2) mengatakan “ Tiap tiap warga Negara berhak atas pekerjaan dan kehidupan yang layak bagi kemanusian “. Ayat ini memuat pengakuan dan jaminan bagi semua warga Negara untuk mendapatkan pekerjaan dan mencapai tingkat kehidupan yang layak bagi manusia. Pancasila adalah pandangan hidup yang berkembang dalam kehidupan sosial dan budaya Indonesia. Modernisasi mengharuskan masyrakat Indonesia harus lebih memahami nilai-nilai dari pancasila. Pancasila lahir pada tanggal 1 juni.

Di Indonesia bidang ketenagakerjaan mengatur tentang hubungan kerja antara pemberi kerja dengan pekerja, dimana pemberi kerja memberikan perintah pekerjaan yang harus dilaksanakan oleh pekerja, dan pekerja akan diberi upah sebagai imbalan terhadap pekerjaan yang telah dilakukannya. Bekerja merupakan usaha yang dilakukan oleh seseorang untuk mendapatkan penghasilan agar dapat memenuhi semua kebutuhan hidupnya. Dalam usaha untuk mendapatkan penghasilan tersebut, seseorang pasti akan memerlukan orang lain dalam hubungan saling bantu-membantu dan saling tukar bantu dalam memberikan segala apa yang telah dimiliki dan menerima segala apa yang masih diperlukan dari orang lain. Seseorang yang kurang memiliki modal

\footnotetext{
${ }^{1}$ Sunaryati Hartono, 1982 Hukum Ekonomi Pembangunan Indonesia, Binacipta, Bandung, hlm. 17
} 
atau penghasilan inilah yang akan memerlukan pekerjaan yang dapat memberikan penghasilan kepadanya, setidaknya sebatas kemampuan. ${ }^{2}$

Reformasi dalam bidang hukum ketenagakerjaan dilakukan dengan tujuan untuk memperbaiki dan meningkatkan mutu tenaga kerja serta kesejahteraan tenaga kerja. Reformasi di bidang hukum ketenagakerjaan diawali dengan dikeluarkannya Undang-undang Nomor 21 Tahun 2000 tentang Serikat Pekerja/Serikat Buruh. Kemudian diikuti dengan keluarnya UndangUndang Nomor 13 Tahun 2003 tentang Ketenagakerjaan.

Akan tetapi dalam pelaksanaannya pada waktu sekarang ini, tujuan dari reformasi peraturan hukum di bidang ketenagakerjaan yang dilakukan dengan tujuan untuk memberikan rasa keadilan dan perlindungan terhadap buruh/perkeja serta untuk memenuhi amanat Undang-Undang Dasar 1945 yaitu untuk melakukan pembangunan manusia Indonesia seutuhnya dan pembangunan masyarakat Indonesia seluruhnya, dan untuk meningkatkan harkat, martabat dan harga diri tenaga kerja serta mewujudkan masyarakat sejahtera, adil, makmur dan merata baik materil maupun sprituil belum berjalan sesuai dengan yang dicita-citakan. Penyebab terjadinya akibat tersebut terdapat berbagai faktor, salah satunya adalah dengan cara mempekerjakan pekerja dengan sistem Perjanjian Kerja Waktu Tertentu (PKWT). Faktanya praktek kerja ousoursing saat ini lebih banyak merugikan pekerja karena hubungan kerja selalu tidak tetap (PKWT), upah lebih rendah,jaminal sosial pun walaupun ada hanya sebatas minimal, serta tidak adanya jaminan pengembangan karir. ${ }^{3}$ Dengan hal ini penerapatan kerja dalam waktu tertentu (PKWT) perlu ditinjau dalam konsep maslahah mursalah dan keadilan pancasila agar penerapan kerja dalam waktu tertentu (PKWT) bisa pencapai kebaikan (maslahah) dan berkeadilan bagi semua.

Maslahah mursalah adalah menetapkan hukum suatu masalah yang tidak ada nashnya atau tidak ada ijma'nya, dengan berdasar pada kemaslahatan. Al-

\footnotetext{
${ }^{2}$ A. Ridwan Hilmim, Sari Hukum Perburuhan, (Jakarta : PT. Pradnya Paramita, 1987), hlm. 3.

${ }^{3}$ St Laksono Utomo,SH,MH, Permasalahan Outsorsing dalam ketenagakerjaan di Indonesia Jurnal Lex Republica Vol 1, Hal 2, Januari 2014
} 
khawarizmi mendefinisikan maslahah mursalah sebagai berikkut : "Memelihara tujuan hukum Islam dengan mencegah kerusakan/ bencana (mafsadat) atau halhal yang merugikan diri manusia (al-khalq)". Penggunaan maslahah mursalah adalah ijtihad yang paling subur untuk menetapkan hukum yang tak ada nashnya dan jumhur ulama menganggap maslahah mursalah sebagai hujjah syari'at karena:

1. Semakin tumbuh dan bertambah hajat manusia terhadap kemaslahatannya ,jika hukum tidak menampung untuk kemaslahatan manusia yang dapat diterima,berarti kurang sempurnalah syari'at mungkin juga beku.

2. Para shahabat dan tabi'in telah mentapkan hukum berdasarkan kemaslahatan,seperti abu bakar menyuruh mengumpulkan musyaf alqur'an demi kemaslahatan umum.

Diantara ulama yang banyak menggunakan maslahah mursalah ialah imam malik,dengan alasan,bahwa tuhan mengutus rasulnya untuk kemaslahatan manusia, maka kemaslahatan ini jelas dikehendaki syara',sebagaimana Allah berfirman:

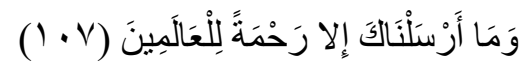

"tidaklah semata-mata aku mngutusmu (muhammad) kecuali untuk kebaikan seluruh alam". (Q.S Al-Anbiya 107).

Sedangkan menurut imam ahmad,bahwa maslahah mursalah adalah suatu jalan menetapkan hukum yang tidak ada nash dan ijma'.

Menurut pendapat R. Subekti ${ }^{4}$ perjanjian adalah suatu peristiwa dimana dua orang atau lebih itu saling berjanji untuk melaksanakan sesuatu hal. Pasal 1233 Kitab Undang-Undang Hukum Perdata (KUHPerdata) menyebutkan bahwa perikatan dapat lahir dari perjanjian atau dari Undang-Undang (verbintenissen onstaan uit overeenkomst, of uit de wet). Ketentuan ini terlihat bahwa KUHPerdata membedakan perikatan yang lahir dari perjanjian dan perikatan yang lahir dari Undang-Undang. Perikatan yang lahir dari perjanjian artinya dua orang atau lebih dapat menjadi terikat untuk melakukan hak dan

\footnotetext{
${ }^{4}$ Subekti, Aneka Perjanjian, (Bandung: PT. Citra Aditya Bakti, 2014), hlm.57
} 
kewajiban masing-masing dikarenakan mereka menyetujui sebuah perjanjian. Perjanjian itu menerbitkan suatu perikatan antara dua orang yang membuatnya. Perjanjian yang telah dibuat oleh para pihak akan mempunyai kekuatan mengikat sebagaimana Undang-Undang bagi keduanya, hal ini dikenal dengan asas pacta sunt servanda.

Berdasarkan penjelasan tersebut diatas diartikan bahwa perusahan dan karyawan telah melakukan pengikatan yang lahir dari perjanjian untuk melakukan hak dan kewajiban masing-masing serta menjadi Undang-Undang bagi para pihak yang saling sepakat, hal ini dikarenakan perusahan dan Karyawan telah setuju dengan Perjanjian Kerja Waktu Tersebut (PKWT), yang selanjutnya disebut Perjanjian Kerja.

\section{B. PERMASALAHAN}

Berdasarkan latar belakang tersebut di atas dan untuk lebih terfokus dalam membahas tulisan ini sehingga mampu menguraikan pembahasan dengan tepat, maka disusun beberapa permasalahan. Adapun perumusan masalah ini adalah sebagai berikut:

1. Bagaimana Pengaturan PKWT dalam UU NO 13 Tahun 2003 Tentang Ketenagakerjaan?

2. Bagaimana Pengaturan PKWT dalam UU NO 13 Tahun 2003 Tentang Ketenagakerjaan sesuai Maslahah Mursalah dan Keadilan Pancasila

\section{METODE PENELITIAN}

Metode yang digunakan dalam penulisan ini adalah metode pendekatan yuridis normatif. Menurut Bogdan dan Taylor, metode pendekatan normatif adalah untuk mengkaji penerapan kaidah-kaidah atau norma-norma dalam hukum positif. Penelitian ini disebut juga penelitian kepustakaan atau studi dokumen, karena penelitian ini lebih banyak akan dilakukan melalui studi kepustakaan atau lebih dikenal dengan studi pada data sekunder. ${ }^{5}$

Ketenagakerjaan dalam kajian Marsalahah Mursalah dan keadilan Pancasila berdasarkan Undang-Undang pada:

${ }^{5}$ Soerjono Soekanto dan Sri Mamudji, Penelitian Hukum Normatif, Suatu Tinjauan Singkat, (Jakarta: Raja Grafindo Persada, 2006), hlm. 13-14. 
a) Undang-Undang Dasar Republik Indonesia Tahun 1945;

b) Kitab Undang-Undang Hukum Perdata

c) Undang-Undang Nomor 13 tahun 2003 tentang Ketenagakerjaan

Bahan hukum sekunder adalah bahan-bahan yang erat hubungannya dengan bahan hukum primer dan dapat membantu menganalisis dan memahami bahan hukum primer, yang terdiri dari:buku-buku hasil karya para sarjana, hasil-hasil penelitian, berbagai hasil pertemuan ilmiah yang berkaitan dengan permasalahan yang dibahas. Hukum tersier adalah bahan-bahan yang memberikan informasi tentang bahan hukum primer dan bahan hukum sekunder, yang terdiri dari Kamus Hukum, Kamus-kamus lainnya yang menyangkut penelitian ini.

\section{PEMBAHASAN}

Pembuatan Perjanjian kerja waktu tertentu pada umumnya dibuat oleh pengusaha kepada karyawan yang bertujuan untuk melindungi pengusaha dan pekerja. Tetapi dalam hal ini penulis menitikberatkan serta menganalisis Perjanjian kerja waktu tertentu (PKWT) yang dibuat oleh Pengusaha kepada karyawannya, yang memiliki peranan yang cukup besar baik terhadap Pengusaha maupun pekerja. Hal ini dapat diketahui karena Perjanjian kerja waktu tertentu tersebut merupakan suatu ketentuan hukum yang bersifat mengikat bagi Pengusaha di dan pekerja. Dalam Perjanjian kerja waktu tertentu telah diatur ketentuan-ketentuan tentang hal yang berhubungan dengan pekerja dan Pengusaha, jika Perjanjian kerja waktu tertentu yang telah disetujui tersebut dilanggar oleh salah satu pihak maka pihak yang dirugikan dapat menuntut sesuai dengan ketentuan yang ada dalam Perjanjian Kerja Waktu Tertentu ${ }^{6}$.

Penyusunan Perjanjian kerja waktu tertentu di Pengusaha dibuat menurut format atau bentuk yang dibuat oleh Pengusaha dan tidak melalui penyusunan perjanjian secara bersama-sama dengan pekerja kontrak dimana sudah tercantum hak dan kewajiban pekerja sehingga pekerja hanya mengisi: ${ }^{7}$

(1) Identitas para pihak.

\footnotetext{
${ }^{6}$ Salim Hs, Hukum Kontrak Teori \& penyusunan Kontrak, Sinar Grafika, Jakarta, 2012, Hal 65

${ }^{7}$ Zaeni Asyhadie,Hukum kerja Hukum Ketenagakerjaan Bidang kerja,PT grafindo persada, Jakarta 2015. Hal.65
} 
e-ISSN : 2621-4105

(2) Tanggal pembuatan perjanjian kerja waktu tertentu.

(3) Jabatan bagi pekerja kontrak dan wilayah kerjanya.

(4) Jangka waktu perjanjian kerja waktu tertentu.

(5) Tanda tangan dan nama dari para pihak yang melakukan perjanjian kerja waktu tertentu.

Adapun format perjanjian kerja waktu tertentu di Pengusaha adalah sebagai berikut:

a. Tanggal pembuatan perjanjian kerja waktu tertentu dan kesepakatan kedua belah pihak untuk melakukan perikatan.

b. Identitas pengusaha (pihak I). Berisi tentang nama, jabatan, alamat, yang mewakili atau pihak Pengusaha.

c. Identitas pekerja (pihak II). Berisi nama, jabatan atau jenis pekerjaan yang akan diperoleh, dan alamat dari pekerja.

d. Jangka waktu perjanjian kerja waktu tertentu. Dalam poin ini menyatakan bahwa:" kontrak kerja ini berlaku 1 (satu) tahun dan dapat diperpanjang kedua belah pihak".

a. Ketentuan aturan kerja. Dalam poin ini menyatakan bahwa : "pihak kedua bersedia menerima sanksi apabila selama masa kontrak melakukan tindakan atau perbuatan yang merugikan perusahaan, dan siap untuk mengundurkan diri atau diberhentikan oleh perusahaan".

b. Jenis pekerjaan. Berisi nama jabatan atau jenis pekerjaan bagi pihak kedua yang dalam hal ini adalah pekerja.

c. Ketentuan tugas. Dalam poin ini menyatakan bahwa: " pihak kedua bersedia mematuhi segala ketentuan peraturan dan tata tertib yang dikeluarkan oleh perusahaan dalam hal ini berupa Perjanjian Kerja Bersama (PKB)".

d. Hak-hak dan perlindungan pekerja sebagai pihak kedua.Berisi tentang ketentuan upah/gaji, pemberian seragam kerja, jaminan kesehatan, pengikutsertaan dalam program jamsostek. 
e. Penutup. Surat perjanjian ini dibuat dan ditandatangani oleh kedua belah pihak dalam rangkap dua yang memiliki nilai hukum yang sama

Dalam suatu pembuatan perjanjian kerja kedudukan para pihak harus seimbang dalam menentukan isi perjanjian. Perjanjian kerja waktu tertentu di Pengusaha dibuat dalam bentuk kontrak baku. Kontrak baku adalah suatu kontrak yang sudah dicetak secara baku dalam bentuk formulir-formulir tertentu, yang menempatkan pihak lain tidak mempunyai posisi tawar-menawar tetapi hanya menempatkan pada posisi menerima atau menolak kontrak tersebut. ${ }^{8}$

Ketidakjelasan dalam ketentuan mengenai PKWT seperti inkonsistensi antara Pasal yang satu dengan Pasal yang lainnya, masih menjadi problematik, karena Pekerja yang bekerja atas dasar perjanjian kerja waktu tertentu kurang mendapatkan perlindungan hukum jika dibandingkan dengan pekerja yang bekerja atas dasar PKWTT. Praktik-praktik yang menyimpang dari ketentuan Undang-Undang ini merupakan salah satu dari tuntutan Karyawan, khususnya karyawan Notaris yang saat ini sering dilakukan.

Seharusnya, terkait dengan pelaksanaan PKWT di masa mendatang harus lebih diperhatikan mengingat waktu bekerja yang relatif singkat. Selain itu, hakhak pekerja yang terutama tercermin dalam ukuran take home pay, bagi PKWT sebaiknya harus lebih tinggi dibandingkan dengan pekerja PKWTT pada jenis pekerjaan/tugas yang sama di suatu perusahaan. Menurut Radbruch dari tiga nilai dasar hukum jika terjadi ketegangan antara nilai-nilai dasar tersebut, harus menggunakan dasar atau asas prioritas dimana prioritas pertama selalu jatuh pada nilai keadilan, baru nilai kegunaan atau kemanfaatan dan terakhir kepastian hukum.Ini menunjukkan bahwa Radbruch menempatkan nilai keadilan lebih utama daripada nilai kemanfaatan dan nilai kepastian hukum dan menempatkan nilai kep astian hukum dibawah nilai kemanfaatan hukum. ${ }^{9}$

1) Nilai Keadilan (Filosofis) ${ }^{10}$

\footnotetext{
${ }^{8}$ Lalu Husni, Pengantar Hukum Ketenagakerjaan Edisi Revisi, PT. Grafindo Persada, Jakarta 2015, hlm 65.

${ }^{9} \mathrm{I}$ bid

${ }^{10}$ Widhi Handoko, http://lapatuju.blogspot.com/2013/03/keadilan-kemanfaatan-dankepastian.html diakses pada tanggal 12 April 2018
} 
Nilai dasar yang pertama adalah keadilan hukum, sebagaimana dikemukakan Muchsin bahwa keadilan merupakan salah satu tujuan dari hukum selain dari kepastian hukum itu sendiri dan juga kemanfaatan hukum.Makna keadilan itu sendiri masih menjadi perdebatan, keadilan terkait dengan pendistribusian yang merata antara hak dan kewajiban.

Keadilan merupakan salah satu tujuan hukum yang paling banyak dibicarakan sepanjang perjalanan sejarah filsafat hukum.Tujuan hukum bukan hanya keadilan, tetapi juga kepastian hukum dan kemanfaatan hukum.Idealnya, hukum memang harus mengakomodasikan ketiganya.Putusan hakim misalnya, sedapat mungkin merupakan resultant dari ketiganya.Sekalipun demikian, tetap ada yang berpendapat, bahwa di antara ketiga tujuan hukum tersebut, keadilan merupakan tujuan hukum yang paling penting, bahkan ada yang berpendapat, bahwa keadilan adalah tujuan hukum satu-satunya.

\section{2) Nilai Kemanfaatan (Sosiologis) ${ }^{11}$}

Nilai dasar yang kedua adalah kemanfaatan hukum. Penganut aliran utilitas menganggap bahwa tujuan hukum semata-mata untuk memberikan kemanfaatan atau kebahagiaan yang sebesar-besarnya bagi sebanyak-banyaknya warga masyarakat.Penanganannya didasarkan pada filsafat sosial, bahwa setiap warga masyarakat mencari kebahagiaan, dan hukum merupakan salah satu alatnya.

Prinsip utility tersebut dikemukakan oleh Bentham dalam karya monumentalnya Introduction to the Principles of Morals and Legislation.Bentham mendefinisikannya sebagai sifat segala benda tersebut cenderung menghasilkan kesenangan, kebaikan, atau kebahagiaan, atau untuk mencegah terjadinya kerusakan, penderitaan, atau kejahatan, serta ketidakbahagiaan pada pihak yang kepentingannya dipertimbangkan.

\section{3) Nilai Kepastian Hukum (dokmatic)}

Nilai dasar yang ketiga yakni kepastian hukum. Kepastian hukum secara normatif adalah ketika suatu peraturan dibuat dan diundangkan secara pasti karena mengatur secara jelas dan logis. Jelas dalam artian tidak menimbulkan keragu-

${ }^{11} \mathrm{Ibid}$ 
e-ISSN : 2621-4105

raguan (multi-tafsir) dan logis dalam artian ia menjadi suatu sistem norma dengan norma lain sehingga tidak berbenturan atau menimbulkan konflik norma. Konflik norma yang ditimbulkan dari ketidakpastian aturan dapat berbentuk kontestasi norma, reduksi norma atau distorsi norma. Pemikiran mainstream beranggapan bahwa kepastian hukum merupakan keadaan dimana perilaku manusia, baik individu, kelompok, maupun organisasi, terikat dan berada dalam koridor yang sudah digariskan oleh aturan hukum.

Pengertian sepakat dalam perjanjian kerja dapat diartikan sebagai persyaratan kehendak para pihak. Pernyataan pihak yang menwarkan disebut tawaran dan pernyataan pihak yang menerima tawaran disebut akseptasi. Mengenai hal ini ada beberapa ajaran yaitu: ${ }^{12}$

1. Teori kehendak (wilstheorie) yang mengatakan bahwa kesepakatan terjadi pada saat kehendak pihak penerima dinyatakan.

2. Teori pengiriman (verzendtheorie) yang mengatakan bahwa kesepakatan terjadi pada saat kehendak yang dinyatakan itu dikirim oleh pihak yang menerima tawaran.

3. Teori pengetahuan (vernemingstheorie) yang mengatakan bahwa pihak yang menawarkan seharusnya sudah mengetahui bahwa tawarannya sudah diterima.

4. Teori kepercayaan (vertrowenstheorie) yang mengatakan bahwa kesepakatan itu terjadi pada saat pernyataan kehendak dianggap layak diterima oleh pihak yang ditawarkan.

\section{Bagaimana Pelaksanaan PKWT Dianalisis Dari Aspek Maslahah Mursalah dan keadilan pancasila}

PKWT beberapa tahun terakhir ini sudah menjadi bagian dari rantai peraturan pekerja yang tidak dapat dipisahkan di tengah ketidak jelasan dan kepastian akan maraknya pemutusan hubungan kerja. Tetapi pekerj pada umumnya hanya bisa pasrah akan pada peraturan perusahaan yang selama ini lebih

${ }^{12}$ Waro Muhammad, Makalah Hukum Perjanjian Kerja, (10 Februari 2012),http://waromuhammad.blogspot.co.id/2012/02/perjanjian-kerja.html, diakses pada tanggal 17 Januari 2018 
menguntungkan paada pengusaha saja, padahal secara UU sudah jelas akan aturan yang bisa memberikan win win solusi baik kepada pengusaha maupun kepada pekerja. Adanya PKWT menimbulkan perbedaan pendapat bagi sebagian pihak. memiliki nilai positif untuk pengusaha, karena mudah untuk kepentingan buged perusahan yang tidak terlalu banyak mengeluarkan banyak uang untuk kesejahteraan pekerjanya. disisi lain sekaligus memberi kerugian bagi sebagian pekerja lainnya yang tidak mendapat penghasilan yang memuaskan akibat dari PKWT ini. Dilema lainnya, pada satu sisi, keberadaan PKWT dianggap sangat membantu pengusaha dalam memecahkan kendala terhadap mengurangi biaya pengeluaran perusahan. Sisi lain memperlihatkan bahwa keberadaan PKWT dianggap bermasalah dalam Penerapanya.

PKWT yang ada saat ini tercipta dari adanya hubungan kerja antara pengusaha dengan pekerja. Pengusaha yang dalam hal ini adalah sebuah perusahaan berbentuk perseroan terbatas yang memberikaan pekerjaan kepada seseorang yang diberikan pekerjaan dengan ikatan waktu tertentu yang seharusnya bisa ditetapkan menjdi karyawan tetap dalam perusahan tersebut jika kalau telah menjalani pekerjaan diadakan untuk paling lama 2 (dua) tahun dan hanya boleh diperpanjang 1 (satu) kali untuk jangka waktu paling lama 1 (satu) tahun seperti tertuang dalam pasal 59 ayat (4) UU N0.13 Tahun 2013 Tentang Ketenagakerjaan., tetapi pada kenyataan masih banyak pekerja yang belum diangkat menjadi menjadi karayawan tetap meskipun masa kerjanya lebih dari 10 tahun diperusahan tersebut,karena aturan yang ada dalam perundangan sering dipelintir oleh sebagian pengusaha untuk mengakali pengeluaraan peruasahan karena lebih menekan biaya biaya pengeluaran yang seharusnya diberikan kepada pekerja tetap cukup diberikan kepada pekerja tidak tetap saja.

Seiring bertambahnya jumlah populasi manusia dan tingkat kebutuhan layak masyarakat meningkat, maka semua orang baik pengusaha selaku pemberi kerja dan buruh selaku pekerja membutuhkan pemasukan dan jaminan sosial yang tinggi juga maka Hak dan Kwajiban sebagai pengusaha dan pekerja dijalankan 
sesuai dengan maslahah mursalah dan berkeadilan pancasila maka tidak akan adanya ketimpangan maupun penyimpangan dalam praktek kehidupanya, karena didalam pancasila salah satunya mengajarkan dan mengamalkan tentang rasa berkeadilan dan berprikemanusian yang adil dan beradab, sehingga kita dituntut menjadi manusia yang senantiasa jujur dan mencintai sesamanya bila itu diaplikasikan secara nyata dalam PKWT contohnya maka niscaya tidak akan ada lagi yang namanya penyimpangan dalam bekerja.

Dengan begitu pelaku usaha harus memenuhi syarat agar bisa diizinkan oleh pemerintah dengan melengkapi syarat ketentuan untuk melaksanakan UU no 13 tahun 2003 tersebut wajib mendaftarkan pekerja dalam jaminan jaminan sosial sehingga pekerjanya menjadi nyaman dalam pekerja.

Gustav Radbruch adalah seorang filosof hukum dan seorang ahli hukum dari Jerman yang terkemuka yang mengajarkan konsep tiga ide unsur dasar hukum. Ketiga konsep dasar tersebut dikemukakannya pada era Perang Dunia II. Tujuan hukum yang dikemukakannya tersebut oleh berbagai pakar diidentikan juga sebagai tujuan hukum. Adapun tiga tujuan hukum tersebut adalah keadilan, kepastian dan kemanfaatan. Dari pendapat tersebut, tujuan kemanfaatan pada hukum menjadi corak utama sebagai tujuan keberadaan hukum itu sendiri. Tujuan kemanfaatan itu adalah bekerjanya hukum di masyarakat efektif atau tidak. Dalam nilai kemanfaatan, hukum berfungsi sebagai alat untuk memotret fenomena masyarakat atau realita sosial dan dapat memberi manfaat atau berdaya guna bagi masyarakat. ${ }^{13}$

Selain itu ada juga teori kemaslahatan umum (public interest) sebagai kerangka dasar dari ide pembaruan hukum Islam tetap menjadi sorotan yang secara gradual terus melaju. Para penulis kontemporer dalam bidang hukum Islam atau secara khusus bidang ushul fiqh turut menjadikan teori tentang kemaslahatan sebagai kerangka referensinya. Berbagai kasus dan masalahmasalah baru yang muncul ditinjau dari perspektif hukum Islam dengan menjadikan acuan utamanya adalah dasar kemaslahatan umum bagi kehidupan manusia secara universal.

\footnotetext{
${ }^{13}$ Namid S. Attamimi da Farid Indaris, Ilmu Per Undang-Undangan, Jenis Fungsi dan Materi Muatan, (Yogyakarta: Kanisis, 2007).
} 
Teori kemaslahatan dalam pemikiran Najm al-Din al-Thufi mengemuka secara substantif dalam kerangka kajian legislasi Islam. Kemaslahatan umum sebagai shariah based merupakan tujuan penetapan hukum Islam. Nash atau dalildalil syara' lain merupakan metode untuk merealisasikan tujuan pencapaian kemaslahatan itu. Paradigma ini mengacu pada realitas perubahan sosial, jika pengamalan makna nash sesuai dengan zhahirnya secara probabilitas akan membawa kesenjangan dan kurang menampung rasa keadilan dan muatan kemaslahatan, maka dalam hal ini makna nash itu dipalingkan kepada makna lain yang lebih mengacu kepada rasa keadilan dan mengandung kemaslahatan umum.

Pemikiran al-Thufi juga menyiratkan adanya suatu upaya untuk memperoleh suatu hukum fiqh melalui perluasan makna suatu teks syari'ah yang bersifat eksplisit dengan mengungkap pengertian-pengertian implisitnya. ${ }^{14}$

Ini dilakukan dengan menggali causalegis (illat) suatu nash untuk diterapkan pada kasus-kasus serupa yang secara ekplisit tidak termasuk ke dalamnya. Atau juga dengan menggali semangat, tujuan dan prinsip umum, yang terkandung dalam suatu nash untuk diterapkan secara lebih luas dalam masalah lain yang diharapkan dapat mewujudkan kemaslahatan umum. Corak pemikiran alThufi dalam teori maslahat ini, dalam kerangka pembaruan pemikiran hukum Islam, terlihat dengan pendekatan transformatif.

Pendekatan transformatif mengemuka sebagai suatu pendekatan alternatif dari pendekatan realis-positivistik yang melihat perubahan (change) sebagai suatu sarana untuk menggapai cita kemaslahatan kualitatif dalam visi Ilahiyyah. Esensi kemaslahatan dalam syara' bukan hanya berfungsi sekadar sistem legitimasi tetapi melainkan sebagai pemenuhan terhadap sesuatu yang mendasar mengenai makna dari apa yang tengah terjadi. ${ }^{15}$

Dalam wacana pembaruan pemikiran dalam hukum Islam, teori kemaslahatan dalam pandangan al-Thufi mencakup lapangan mu'amalah dan adat

\footnotetext{
${ }^{14} \mathrm{Al}$-Thufi berbeda dengan persepsi Jumhur ulama yang menyatakan bahwa bila terdapat pertentangan antara nash dengan mashlahah, maka nash harus didahulukan. Dalam pemikiran al-Thufi, meskipun nash maupun ijma' menyalahi pertimbangan maslahat, maka yang harus diprioritaskan adalah pertimbangan kemaslahatan.

${ }^{15}$ Masdar F. Mas'udi, Memahami Ajaran Suci dengan Pendekatan Transformasi dalam Polemik Reaktualisasi Ajaran Islam, (Jakarta: Pustaka Panjimas, 1988), hlm. 180.
} 
e-ISSN : 2621-4105

kebiasaan. Karena, memang bidang-bidang ini yang rentan terhadap berbagai dinamika perubahan. Sedangkan dalam lapangan ibadah adalah semata hak prerogatif Tuhan. Hakekat yang terkandung dalam ibadah, baik kualitas maupun kuantitas, waktu dan tempat, tidak mungkin diketahui kecuali hanya ditentukan dalam syara'. Kemashlahatan umum dalam hal ini tetap menjadi tujuan syara'. Artinya bahwa keberadaan PKWT juga harus bisa membantu pekerja dalam melakukan aktifitastanpa harus takut adanya pemutusan kerja sepihak oleh suatu perusahanya. Selain itu, juga dapat dipatuhi sebagaimana aturan aturan didalamnya bagi sebagian pengusaha yang sebelumnya tidak memperhatikan kesejahteraan pekerjanya.

\section{E. PENUTUP}

Pelaksanaan perjanjian kerja waktu tertentu (PKWT) oleh pengusaha terhadap karyawannya serta apa yang mendasari pengusaha mengikat karyawan dengan perjanjian kerja waktu tertentu (PKWT) yaitu penyusunan Perjanjian kerja waktu tertentu (PKWT) pengusaha dibuat menurut format atau bentuk yang dibuat oleh pengusaha dan tidak melalui penyusunan perjanjian secara bersama-sama dengan pekerja kontrak dimana sudah tercantum hak dan kewajiban pekerja sehingga pekerja hanya mengisi: (1) Identitas para pihak, (2) Tanggal pembuatan perjanjian kerja waktu tertentu, (3) Jabatan bagi pekerja kontrak dan wilayah kerjanya, (4) Jangka waktu perjanjian kerja waktu tertentu dan (5) Tanda tangan dan nama dari para pihak yang melakukan perjanjian kerja waktu tertentu. Mengenai yang mendasari pihak mengikat karyawan perusahan dengan perjanjian kerja waktu tertentu adalah (1) Faktor pengusaha yang ingin mengambil keuntungan sebesar mungkin, (2) Faktor kedudukan (Tawar Menawar) perusahan dan karyawan yang berbeda dalam membuat perjanjian dan (3) Faktor Peraturan Perundang-Undangan yang tidak tegas. Bagi Dinas Perindustrian Dan Tenaga Kerja diharapkan agar lebih memanfaatkan Sumber Daya Manusia (SDM) yang ada pada Dinas Perindustrian Dan Tenaga Kerja tersebut dan diharapan dapat menajalankan tugas dan perannya sesuai dengan ketentuan peraturan perundang-undangan yang berlaku, sehingga 
tenaga kerja khususnya bagi Karyawan lebih terjamin nilai kepastian hukum, nilai kemanfaatan dalam perjanjian bagi para pihak serta terwujudnya nilai keadilan bagi para pihak.

Bagi pengusaha diharapkan lebih memperhatikan hak-hak karyawan dan menerapkan suatu kepastian maslahah mursalah yang membawa kebaikan dalam mengikat pekerja/karyawan dengan perjanjian kerja waktu tertentu (PKWT), sehingga dapat terwujudnya Kebutuhan Hidup Yang Layak (KHL) bagi tenaga kerja yang ada di Indonesia yang telah di amanatkan oleh Undang-Undang Nomor 13 Tahun 2003 Tentang Ketenagakerjaan serta Undang-Undang Dasar Tahun 1945.

\section{DAFTAR PUSTAKA}

\section{Buku}

A. Ridwan Hilmim, 1987, Sari Hukum Perburuhan, PT. Pradnya Paramita, Jakarta. Achmad Busro, 2013 Kapita Selekta Hukum Perjanjian, Pohon Cahaya, Yogyakarta.

Cholid Narbuko dan H. Abu Achmadi, 2002, Metodologi Penelitian, PT. Bumi Aksara, Jakarta.

Lalu Husni, 2015, Pengantar Hukum Ketenagakerjaan, Edisi Revisi, PT. Grafindo Persada, Jakarta.

Masdar F. Mas'udi, 1988, Memahami Ajaran Suci dengan Pendekatan Transformasi dalam Polemik Reaktualisasi Ajaran Islam, Pustaka Panjimas, Jakarta.

Mukti Fajar ND dan Yulianto Achmad, 2010, Dualisme Penelitian Hukum Normatif dan Empiris, Pustaka Pelajar, Yogyakarta.

Namid S. Attamimi da Farid Indaris, 2007, Ilmu Per Undang-Undangan, Jenis Fungsi dan Materi Muatan, Kanisis, Yogyakarta.

Salim Hs, 2012, Hukum Kontrak Teori \& penyusunan Kontrak, Sinar Grafika, Jakarta.

Soerjono Soekanto dan Sri Mamudji, 2006, Penelitian Hukum Normatif, Suatu Tinjauan Singkat, Raja Grafindo Persada,Jakarta. , 1981, Pengantar Penelitian Hukum, UI Press, Jakarta.

Subekti, 2014, Aneka Perjanjian, PT. Citra Aditya Bakti,Bandung.

Sunaryati Hartono, 1982 Hukum Ekonomi Pembangunan Indonesia, Binacipta, Bandung.

Zaeni Asyhadie, 2015, Hukum kerja Hukum Ketenagakerjaan Bidang kerja,PT grafindo persada, Jakarta.

Zainuddin Ali, 2013, Metode Penelitian Hukum, Sinar Grafika, Jakarta. 
Perjanjian Kerja Waktu Tertentu (PKWT) Dalam UU NO 13 Tahun 2003 Tentang Ketenagakerjaan Suatu Analis Maslahah Mursalah Dan Keadilan Pancasila Aan Ahmad Sancoko

e-ISSN : 2621-4105

\section{Jurnal}

Laksono Utomo, Permasalahan Outsorsing dalam Ketenagakerjaan di Indonesia Jurnal Lex Republica Vol 1, Hal 2, Januari 2014.

\section{Internet}

http://waromuhammad.blogspot.co.id/2012/02/perjanjian-kerja.html.

Widhi Handoko, http://lapatuju.blogspot.com/2013/03/keadilan-kemanfaatandankepastian.html diakses pada tanggal 12 April 2018 